\title{
Driving forest succession in karst areas of Chongqing municipality over the past decade
}

\author{
Qiang Xiao ${ }^{1,2+}$, Yang Xiao ${ }^{3 \dagger}$, Yuan Liu $^{1}$ and Jianping Tao ${ }^{1 *}$
}

\begin{abstract}
Background: Karst areas in southwestern China exhibit ecological degradation in the form of rocky desertification. Local governments launched large-scale afforestation and other ecological restoration programs to curb this trend. Soil thickness is a key limiting factor for vegetation restoration in Karst areas, but the relationship between ecological restoration and soil thickness remains unclear. Further, afforestation consumes large amounts of water, which impacts water supply in karst areas. In this study, we used GIS and statistical analyses to determine rocky desertification sensitivity and its driving factors in karst areas of Chongqing municipality over the past decade.

Results: Soil thickness is one of the key factors that restrict ecological restoration of rocky desertification. From 2000 to 2010, rocky desertification sensitivity in karst areas was on the rise along with an increase in afforestation. Areas of high sensitivity were mainly distributed in Pengshui County, Wulong District, and Youyang County; Shizhu County had the lowest overall incidence of desertification. Spatial distribution of rocky desertification was significantly affected by rainfall and soil thickness. Regression analysis showed that the main factors controlling changes in rocky desertification in natural forest over time were precipitation which explained $23.73 \%$ of total variance, and soil thickness which explained $23.42 \%$ of total variance. Soil thickness and soil water content had a higher correlation coefficient (at 0.516) in natural forests than in planted forests.
\end{abstract}

Conclusion: This study showed that increases in soil thickness in a karst area had a significant positive impact on the fragile ecological environment. This indicates that ecosystem restoration in karst areas will benefit from addressing soil thickness.

Keywords: Rocky desertification, GIS, Karst areas, Ecological restoration, Ecological drivers

\section{Background}

Dissolution and erosion result in bare rock and saltation processes that decrease soil thickness, lead to interspersed distribution of rock and soil surfaces, and create unique rock-soil formations known as karstification (Cao 2012; Cheng et al. 2015). Long-term, strong karstification processes produce a dual-layered structure that impedes water flow and soil resource sustainability. Further, karstification leads to surface water loss and deep

\footnotetext{
* Correspondence: taojianping@163.com

${ }^{\dagger}$ Qiang Xiao and Yang Xiao contributed equally to this work.

${ }^{1}$ Key Laboratory of Eco-environments in Three Gorges Reservoir Region (Ministry of Education), Chongqing Key Laboratory of Plant Ecology and Resources Research in Three Gorges Reservoir Region, School of Life Sciences, Southwest University, Chongqing 400715, China

Full list of author information is available at the end of the article
}

burial of groundwater (Barral et al. 2015). Under such conditions, shallow karst soil layers and its inherent water infiltration processes restrict plant growth (Xiao and $\mathrm{Hu}, 2017)$. Droughts and floods frequently take place when conditions such as shallow soil layer, poor soil water-holding capacity, and limited vegetation cover co-occur (Feng et al. 2015; Cao 2016). Once removed, it may be difficult for vegetation to recover, leading to ecosystem dysfunction.

In karst areas, soil thickness can directly reflect the degree of soil development, which is closely related to soil fertility (Li et al. 2015). Due to its unique climatic conditions and long-term karstification, soil layer in the study area is extremely thin and the rate of soil formation is slow (Gong et al. 2012). Moreover, soil thickness in the study area is highly heterogeneous (Zhang et al. 2014; 
Asante et al. 2018). Soil thickness is an important index in soil degradation research and in assessments of land productivity. In ecologically-fragile karst systems, composed of relatively complex hydrogeological structures, soil thickness and its spatial distribution significantly influence ecological processes on the surface, impacting vegetation and resulting in drought (Jiang et al. 2015).

Because of decreasing arable-land area and increasing poverty, ecosystem degradation progresses in Karst areas. Residents in degraded areas are compelled to engage in unsustainable practices, such as deforestation and agricultural land reclamation, which aggravate environmental degradation (Cao et al. 2007). Because poverty leads to ecosystem degradation, and ecosystem degradation worsens poverty, this vicious circle is a poverty trap; it hinders sustainable socio-economic development of karst areas and threatens long-term livelihoods of the residents (Kong et al., 2015a).

Soil thickness in karst areas is regulated by the supply of available inorganic nutrients and water resources (Wang et al. 2013). Topography is also an important factor in soil thickness; it affects energy distribution, shaping plant community structure and type via its influence on plant growth and reproduction. Soil thickness is a key soil factor which limits forest community successional processes (Braitenberg et al. 2018). Further, thicker soils store more water and nutrients, and can support more plant biomass compared to dry, nutrientpoor shallow soils (Stephens 2017). A severe lack of soil resources and the breakage of steep terrain are the root causes behind differences in soil thickness in karst areas (Chen et al. 2018).

Drought stress is a ubiquitous phenomenon that affects forest succession. Forest structure, species composition, and disturbances within different climates often reflect adaptations to historical drought and heat stress (including chronic, seasonal, and random droughts) (Epting et al. 2018). During forest successional processes, whether natural or man-made, these factors two often influence one another. The combination of different spatial and temporal factors plays an important role in the pattern and process of forest ecosystems. Furthermore, the threat of drought to forest health has been widely recognized by scientists and forest managers, however forest stress resulting from drought has rarely been a clear management goal. One study even reported that the focus in karst areas should be the management of forests under drought stress (Bakalowicz 2005). However, effective and relevant management actions are still needed for landscapes, climate, forest types, and land management objectives.

During forest successional processes, soil thickness acts as the main source of water storage in forest ecosystems. Therefore, the maintenance of soil thickness is key to sustaining forest water resources. To increase the understanding of the effects of management on forest productivity in Karst soils, we aimed to answer the following questions: what management strategies can reduce drought stress in forests, and how can managers implement such strategies? A common practice in forest management is to create forests to reduce water pressure. However, there have been few studies that have assessed the impact of forest management programs on soil thickness and associated drought in karst areas. We selected a second growth forest and a forest plantation in southeast Chongqing municipality to investigate the effects of management strategies on forest ecosystem in Karst soils.

\section{Materials and methods Site descriptions}

The study area, located in southeastern Chongqing municipality in southwestern China, is a World Heritage site of the United Nations Educational, Scientific, and Cultural Organization (UNESCO). The study site includes the following counties: Wulong, Pengshui, QianJiang District, Shizhu, Youyang, and Xiushan. The study site covers $19,800 \mathrm{~km}^{2}$ in the mountainous area of Wuling and Wujiang drainage area. The study site forms the principal southern drainage area and the most important ecological barrier of the Yangtze River Basin (Fig. 1). The area has subtropical humid monsoon climate, with an annual average temperature of approximately $18^{\circ} \mathrm{C}$, annual sunshine hours from 1000 to $1200 \mathrm{~h}$, and average rainfall of 1000-1250 $\mathrm{mm}$ per year with uneven distribution. Soil erosion is severe due to the large number of mountains and slopes, uneven distribution of precipitation, and spatial differences in soil types (He et al. 2016).

Impoverished ethnic minorities form the main local population of the study area. Due to the rugged land surface and high cost of infrastructure, such as transportation, economic development in this area has been restricted. Because the economy remains undeveloped, food and clothing issues have not been thoroughly resolved. The average grain yield is only $200 \mathrm{~kg}$, and the grain yield per capita is $291.5 \mathrm{~kg}$ (Zhang et al., 2016a). The frequent seasonal water scarcity, droughts, landslides, and debris flow disasters exacerbate environmental and existing living conditions.

Desertification in the study area is caused by the fragile karst environment in conjunction with human development activities. Rock dissolution and soil loss processes result in the exposure of rock, the activation of saltation, and the disjunctive distribution of surface rock and soil. Rocky desertification accelerates the deterioration of already fragile karst ecological systems in this area and leads to the loss of land resources where zonal drought conditions occur, thereby posing a threat 


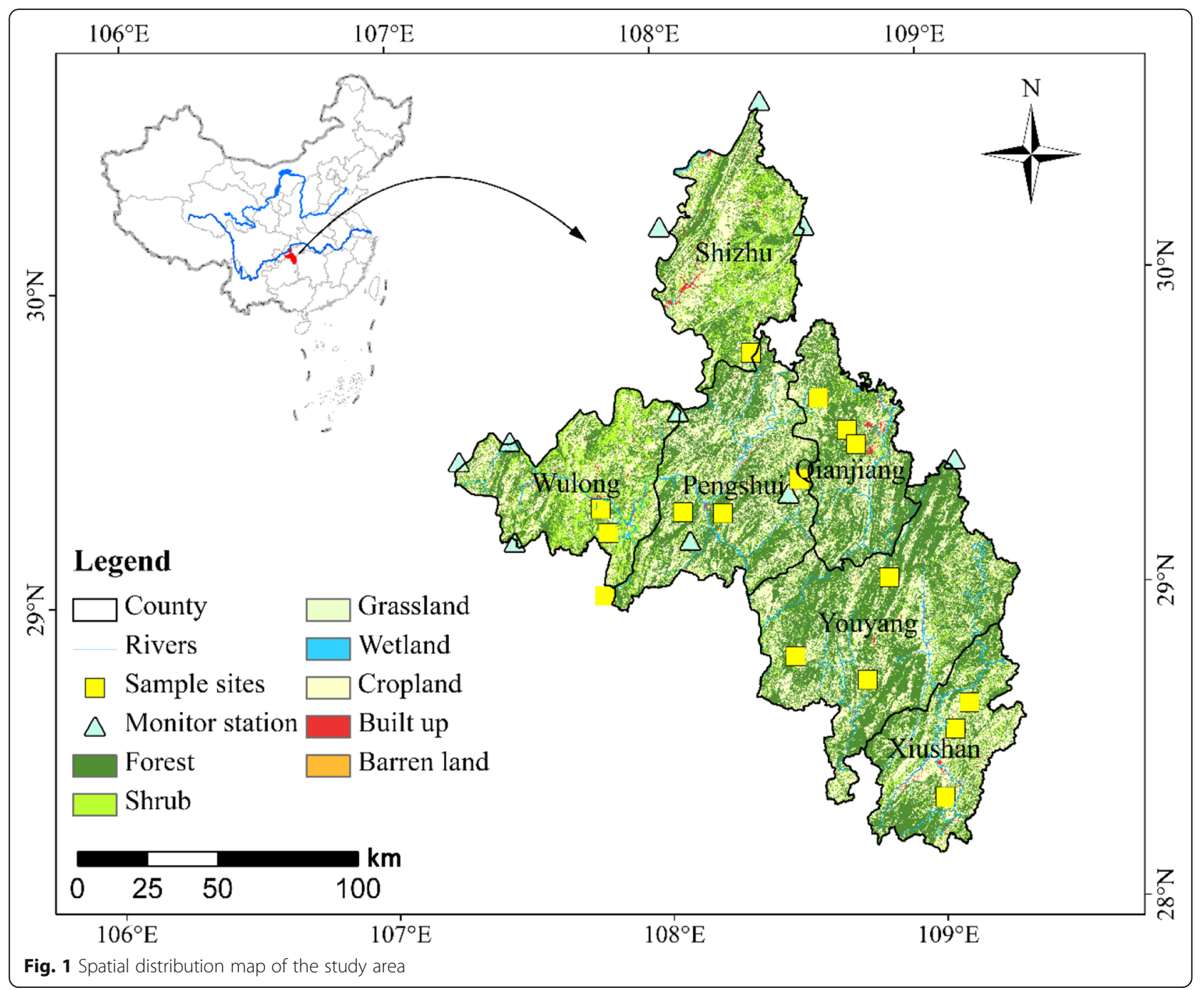

to regional ecological security. The most important impacts on human welfare in these karst areas are lack of water and soil resources (You 2017). Rocky desertification is the most serious ecological problem in this area, hindering sustainable development of the regional economy and society.

\section{Field survey and data sources}

We selected 16 quadrats (each $900 \mathrm{~m}^{2}$ ) in study sites, and divided each quadrat into 9 equal-sized grid cells $\left(10 \times 10 \mathrm{~m}^{2}\right)$. Within each cell, all tree and shrubs were identified to species, and height, diameter at breast height $(\mathrm{DBH})$, and location coordinates were recorded. An average percent area of exposed rock was estimated visually by three observers, and elevation was measured with a hand-held GPS unit. Soil thickness was measured with a measuring stick in 4 corners of each cell, and then the mean value was used as soil depth. We collected soil samples in each cell. Soil was dried in an oven and then weighed to determine soil water content (Fig. $1)$.

In this study, precipitation and temperature data were generated with the thin plate smoothing spline method in the ANUSPLIN software package (developed by Dr. Michael Hutchinson of the Australian National University); this method has been widely used to obtain various regional climatic variables at different scales (Fleury et al. 2007). Daily and monthly precipitation and temperature data from 2000 to 2010 were provided by the National Meteorological Information Centre of the China Meteorological Administration.

The vegetation indices-biomass method and the cumulative net primary production (NPP) method were used to determine aboveground biomass (Giesecke and Bennett, 2004). Specifically, aboveground biomass data were estimated using the vegetation indices-biomass method (for forest/grassland ecosystems) and the cumulative NPP method (for grassland/farmland ecosystems). 
For the vegetation index, we used field measurements of vegetation biomass and remote sensing data to establish the statistical model (Gutierrez et al. 2014). The cumulative NPP method was used to calculate surface biomass to determine the growth periods of grassland and farmland (start time and end time). The NPP algorithm was used to determine the Carnegie-Ames-Stanford Approach model.

To distinguish between ecosystem types, we used the pixel dichotomy model to determine the composition of the ecosystem within karst areas. We used Terra (EOS) satellite MOD13Q1 V005 MODIS vegetation product remote sensing data. We obtained composite 16-day NDVI time series data based on the maximum-value compositing (MVC) method and available quality control data. Vegetation cover data were based on the structuring element in the binary model obtained from the Moderate Resolution Imaging Spectroradiometer (MODIS) image inversion (Han and Liu, 2004). Ecosystem type map was primarily based on the classification technology derived from the Landsat TM data, which uses the object-oriented method. The addition of image spectrum information strengthens the target recognition and classification technologies, providing a rapid, efficient operation. The digital elevation model (DEM), with a spatial resolution of $90 \mathrm{~m}$, was obtained from the international scientific data service platform to interpret slope, slope direction, and elevation information.

County-scale socioeconomic data, including the size of the human population, urban population, rural population, and gross domestic product (GDP), were obtained from the China Statistical Yearbook and Statistical yearbook of Chongqing (State Statistics Bureau, from 2000 to 2010). Ecological policy data from the Natural Forest Conservation Program, the Sloping Land Conversion Program (SLCP), and the Yangtze River Shelterbelt Project were obtained from the China forestry yearbooks. All cartographic data were converted to the same coordinate system (Albers equal-area conic) and the same spatial resolution.

\section{Desertification sensitivity calculation}

We adopted a comprehensive evaluation formula to obtain desertification sensitivity data in the study area (Hyvonen et al. 2000). According to literature, the incidence rates of rocky desertification in limestone, namely, the interbeds between limestone and dolomite and carbonate rocks in clastic rock structures, are much higher (29.86\%, 29.01\% and 29.47\%, respectively); the incidence rate of rocky desertification in dolomite is $19.37 \%$, that of carbonate rock and clastic rock in interbed layers is $15.83 \%$ and that of carbonate rock in the clastic rock layer is only $12.92 \%$ (Jiang et al. 2016).
Sensitivity grading standards of rocky desertification to lithology, precipitation, slope, and vegetation cover are shown in Table 1 (Xiao et al. 2005). Sensitivity of rocky desertification obtained from a single factor analysis does not reflect the degree of possible interactions, especially at regional scales. Therefore, we used the following equation for comprehensive evaluation of rocky desertification sensitivity (Xiao et al. 2005):

$$
S S j=\sqrt[4]{\prod_{i}^{4}} C i
$$

where $S S j$ refers to the $j$-space unit of the rocky desertification sensitivity index, and $C i$ is the $i$-factor sensitivity level value. The final result is graded according to a numerical range (0-9), taking the intermediate value of 4 as the boundary line. The intermediate value 4 (or above 4) is classified as the rocky desertification sensitive area, while other numerical ranges are potentially rocky desertification areas.

\section{Correlation and regression analysis}

We used correlation analysis to determine the effect of natural factors and human activity on trends in natural ecosystems and rocky desertification. The study employed a stepwise regression between changes in rocky desertification and driving forces (Larocque et al. 1998).

Natural factors refer to precipitation, temperature, altitude, slope, soil thickness, soil moisture content. Human activity was defined as population size in rural and urban areas, gross domestic product (GDP), traffic density, and construction of land area. Correlation analysis used the multiple linear regression (MLR) method to identify the level of contribution of various factors to stony desertification, and was conducted with the SPSS software using the county area as a statistical unit. All statistical analyses were performed at a county level using SPSS 20.0 (IBM Corp., Armonk, NY, USA).

\section{Results}

\section{Spatial characteristics and desertification sensitivity}

High values of rocky desertification sensitivity were mainly distributed in high mountain ranges (Table 2). Due to long-term geological processes, limestone lithology is generally non homogeneous in these areas. Given the steep slopes and rainfall intensity, soil erosion is severe in these areas, facilitating rocky desertification (Fig. 2a). Areas of high sensitivity were mainly distributed in Pengshui County, Wulong District, and Youyang County (Fig. 2b). Shizhu County had the lowest sensitivity. The main reason for this was area topography. For example, Pengshui County, Wulong District, and 
Table 1 Classification criteria for effects of desertification sensitivity

\begin{tabular}{|c|c|c|c|c|c|c|}
\hline Grading & $\begin{array}{l}\text { No rocky } \\
\text { desertification }\end{array}$ & Potential sensitive & Mildly sensitive & $\begin{array}{l}\text { Moderately } \\
\text { sensitive }\end{array}$ & Highly sensitive & $\begin{array}{l}\text { Extremely } \\
\text { sensitive }\end{array}$ \\
\hline $\begin{array}{l}\text { Lithological } \\
\text { characters }\end{array}$ & $\begin{array}{l}\text { Insoluble rock, non- } \\
\text { carbonate rocks }\end{array}$ & $\begin{array}{l}\text { Buried soluble rock, insoluble } \\
\text { rock, non-carbonate rock }\end{array}$ & Sub-pure limestone & Impure limestone & Dolomite & $\begin{array}{l}\text { Limestone, } \\
\text { limestone } \\
\text { and } \\
\text { dolomite }\end{array}$ \\
\hline $\begin{array}{l}\text { Precipitation } \\
(\mathrm{mm})\end{array}$ & $<300$ & $<400$ & $400-800$ & $800-1500$ & $1500-2000$ & $2000-2500$ \\
\hline Slope $\left({ }^{\circ}\right)$ & $<3$ & $<5$ & $5-15$ & $15-30$ & $30-45$ & $>45$ \\
\hline $\begin{array}{l}\text { Vegetation } \\
\text { cover (\%) }\end{array}$ & $\begin{array}{l}\text { High cover forestland, } \\
\text { shrubs, grassland } \\
\text { (vegetation-cover > } \\
75 \% \text { ) }\end{array}$ & $\begin{array}{l}\text { High cover forestland, shrubs, } \\
\text { grassland (vegetation-cover > } \\
70 \% \text { ), paddy fields (water } \\
\text { bodies, towns) }\end{array}$ & $\begin{array}{l}\text { Covered forest land, } \\
\text { shrubs, grassland } \\
\text { (vegetation-cover } \\
40 \%-70 \% \text { ) }\end{array}$ & $\begin{array}{l}\text { Low-cover } \\
\text { forestland, shrubs } \\
\text { (vegetation- } \\
\text { coverage }<40 \%)\end{array}$ & $\begin{array}{l}\text { Low-cover } \\
\text { grassland } \\
\text { (vegetation- } \\
\text { coverage < 40\%), } \\
\text { dry land }\end{array}$ & $\begin{array}{l}\text { Bare soil, } \\
\text { bare rock, } \\
\text { no } \\
\text { vegetation }\end{array}$ \\
\hline Assignment & 0 & 1 & 3 & 5 & 7 & 9 \\
\hline
\end{tabular}

Note: 1) No rocky desertification includes mainly non-carbonate rocks and insoluble rock; Potential sensitive includes buried soluble rock, insoluble rock, noncarbonate rock; Mildly sensitive includes sub-pure limestone; Moderately sensitive includes limestone and kata-rocks; Highly sensitive includes dolomite; Extremely sensitive includes limestone, limestone and dolomite (Li et al. 2014). 2) Normalized vegetation index is used to calculate vegetation coverage. NDVI value is composed of information contributed by green vegetation and non-vegetation coverage (Tang et al. 2019)

Youyang County are mainly distributed in the central region of southeastern Chongqing municipality (Fig. 2b), which has a high elevation. The results are similar to rocky desertification sensitivity analytical results. More than half of southeastern Chongqing municipality is covered in rocky desertification and includes Pengshui County, Wulong District, and Youyang County, which account for more than $66 \%$ of the area as a whole.

Figure 3 shows the correlation between recent rates of rocky desertification and afforestation area in the study area, and indicates that the more afforestation activities in the region, the greater the proportion of stony desertification (Fig. 3).

\section{Random sample characteristics of rocky desertification}

Because natural forests are mainly distributed in highaltitude mountainous areas and are consequently less affected by human activity, soil thickness was significantly positively correlated with soil water content with a correlation coefficient of 0.5162 (Fig. 4a). However, there was no significant correlation between soil thickness and rock exposure rate. The overall trend was negative, indicating that the thinner the soil, the higher the probability of rocky desertification (Fig. 4b).

However, samples from planted forests were inherently different from those from natural forests. Planted forests are mainly distributed at low altitudes, which are greatly affected by human activity. Although soil thickness was positively correlated with soil water content (Fig. 5a), there was a significant positive correlation between soil thickness and denudation rate (Fig. 5b). This indicated that the thicker the soil, the higher the probability of rocky desertification. These results contradicted the findings of others, potentially due to the presence in this study site of large areas of cultivation, especially of economic (cash) crops which accelerate regional evapotranspiration and change the nature of soil. Cultivated areas are prone to soil erosion which increases the occurrence of rock exposure, especially under heavy rainfall.

\section{Relationships between rocky desertification and climate and human activity in karst areas}

In natural karst recovery areas, spatial distribution of rocky desertification from 2000 to 2010 was significantly

Table 2 The land areas in different sensitivity grade of rocky desertification and percentages of rocky desertification in each county (area unit, $\mathrm{km}^{2}$; proportional unit, \%)

\begin{tabular}{|c|c|c|c|c|c|c|c|c|}
\hline Name & $\begin{array}{l}\text { No rocky } \\
\text { desertification }\end{array}$ & $\begin{array}{l}\text { Potential rocky } \\
\text { desertification }\end{array}$ & $\begin{array}{l}\text { Mildly } \\
\text { sensitive }\end{array}$ & $\begin{array}{l}\text { Moderately } \\
\text { sensitive }\end{array}$ & $\begin{array}{l}\text { Highly } \\
\text { sensitive }\end{array}$ & $\begin{array}{l}\text { Extremely } \\
\text { sensitive }\end{array}$ & $\begin{array}{l}\text { Rocky } \\
\text { desertification }\end{array}$ & $\begin{array}{l}\text { Rocky desertification } \\
\text { percentage }(\%)\end{array}$ \\
\hline Shizhu & 2304 & 670 & 35 & 9 & 2 & 0 & 716 & 23.71 \\
\hline Qianjiang & 1235 & 920 & 69 & 124 & 50 & 17 & 1180 & 48.86 \\
\hline Wulong & 968 & 1586 & 113 & 106 & 52 & 41 & 1898 & 66.22 \\
\hline Xiushan & 993 & 1168 & 135 & 97 & 31 & 10 & 1441 & 59.20 \\
\hline Youyang & 1359 & 3255 & 204 & 194 & 99 & 49 & 3801 & 73.66 \\
\hline Pengshui & 925 & 2428 & 155 & 284 & 89 & 24 & 2980 & 76.31 \\
\hline Total & 7784 & 10,027 & 711 & 814 & 323 & 141 & 12,016 & 60.69 \\
\hline
\end{tabular}


(a)

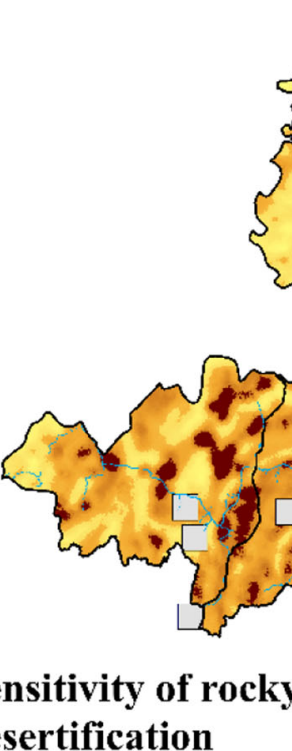

Value

High : 8.85

Low : 1.49 (b)

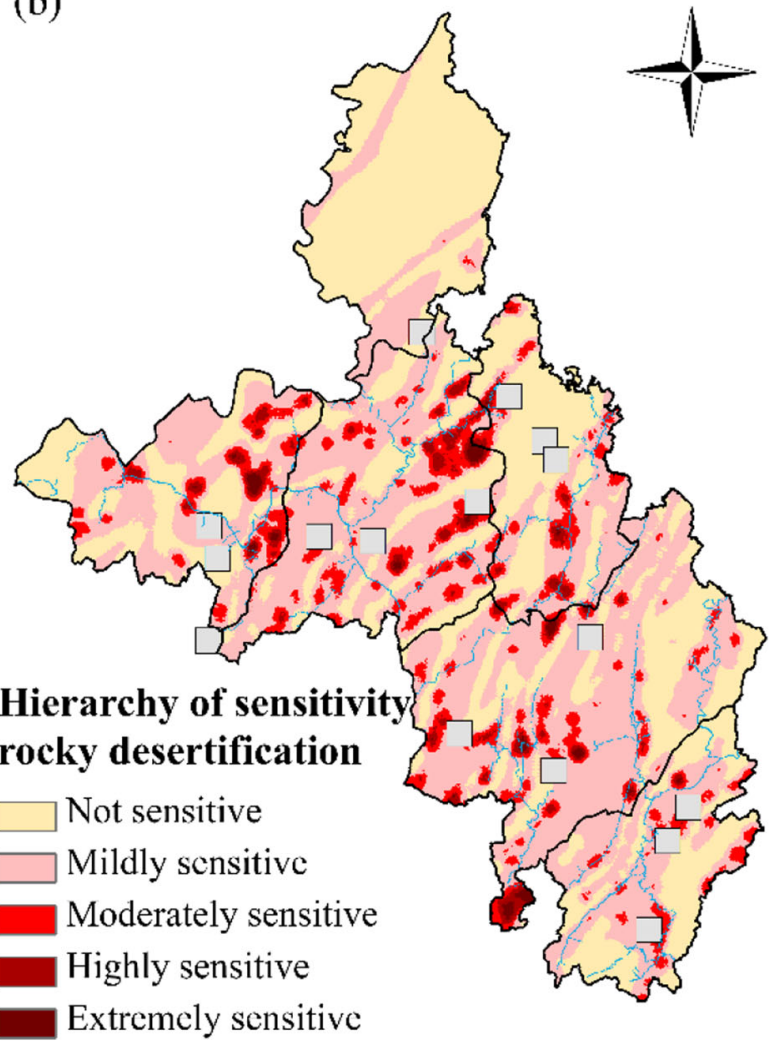

$\begin{array}{lll}0 & 25 \quad 50\end{array}$

$\begin{array}{ll}50 & 100\end{array}$

Fig. 2 Sensitivity diagram of rocky desertification. a Numerical sensitivity diagram of rocky desertification; b Hierarchy diagram of sensitivity rocky desertification. The small box is the mean value of sample points

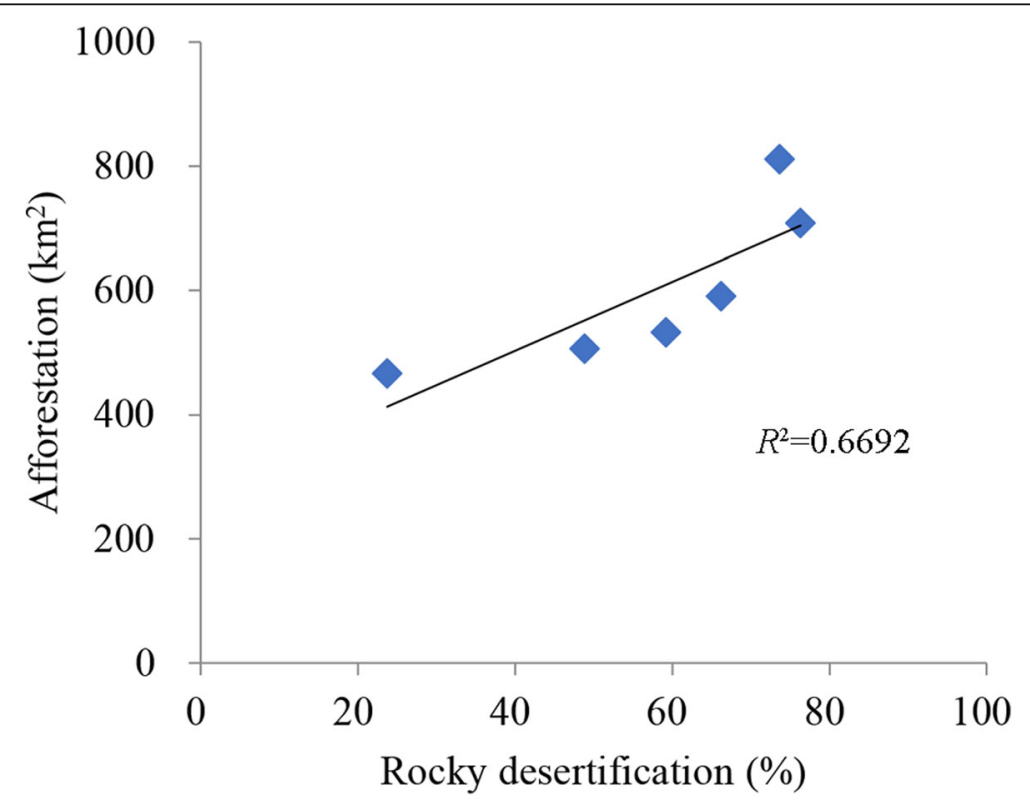

Fig. 3 The relationship between the proportion of rocky desertification area and afforestation area in six counties in southeast Chongqing. The blue squares represent the total artificial forests area in each county 

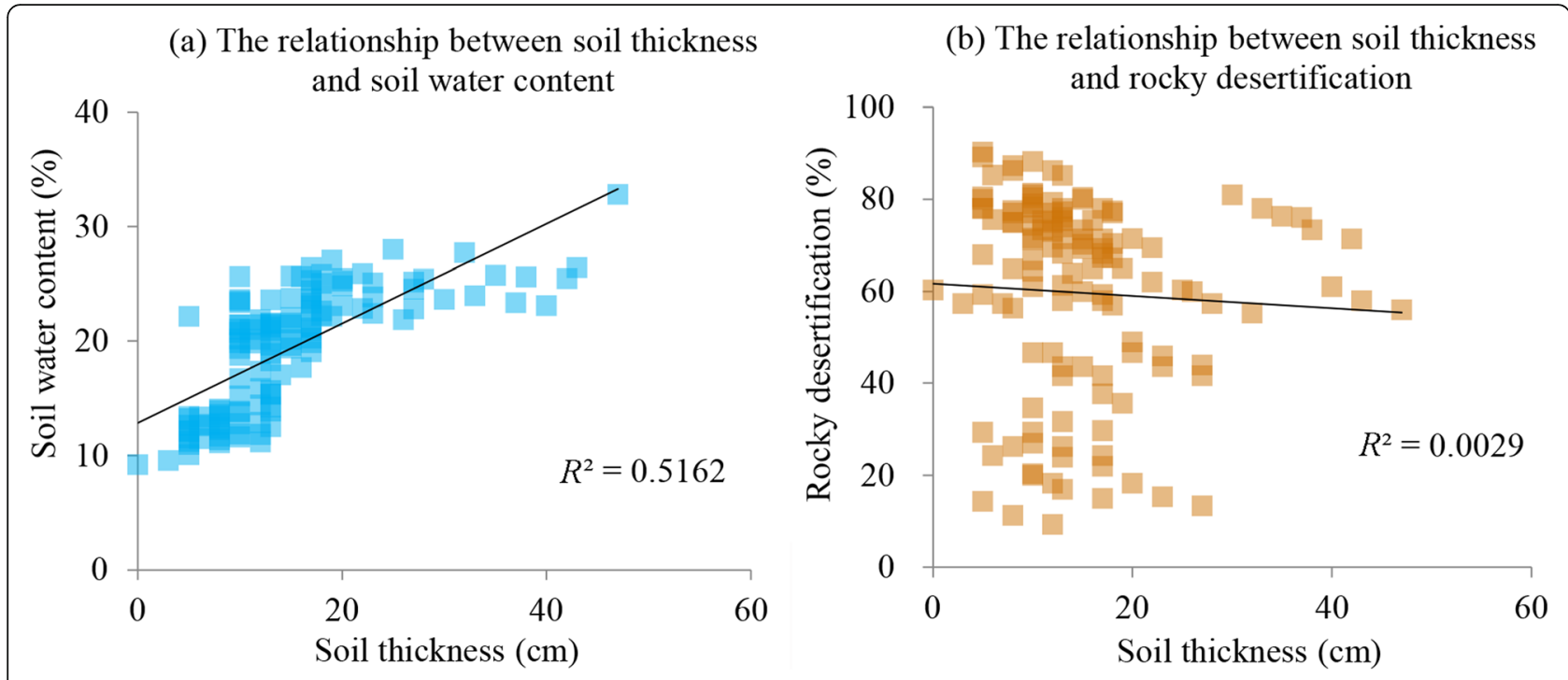

Fig. 4 Correlations between soil thickness and soil water content as well as proportion of rocky desertification in natural forests

affected by rainfall and soil thickness (Table 3). Precipitation explained $23.73 \%(P<0.01)$ of total variance in rocky desertification, and soil thickness explained $23.42 \%(P<0.01)$. Soil moisture content was also one of the main factors affecting changes in rocky desertification. Precipitation exhibited the largest correlation, reaching $R^{2}$ of 0.592 , indicating that rainfall in these areas had a significant impact on rocky desertification.

In artificial karst forest areas, soil thickness was the most important factor for rocky desertification. Results showed that changes in rocky desertification were affected by soil thickness, precipitation, and soil moisture content (Table 4). Precipitation accounted for $22.13 \%$, soil thickness for $24.42 \%$, soil moisture for $12.15 \%$, and traffic density for $10.3 \%$ of total variance. Soil thickness exhibited was the highest correlation, indicating that soil thickness has a significant impact on vegetation change in rocky desertification areas within the study area.

\section{Discussion}

Relationships between rocky desertification sensitivity and afforestation

We found different trends in rocky desertification sensitivity in different areas. In the northwestern area (Pengshui County and Wulong District), rocky desertification sensitivity continually increased; however, it continually decreased in Xiushan County and Shizhu County. One potential reason for these opposing results are the different forest management goals in those regions (Zhang et al., 2016b). Due to its unique dual-layered structure,
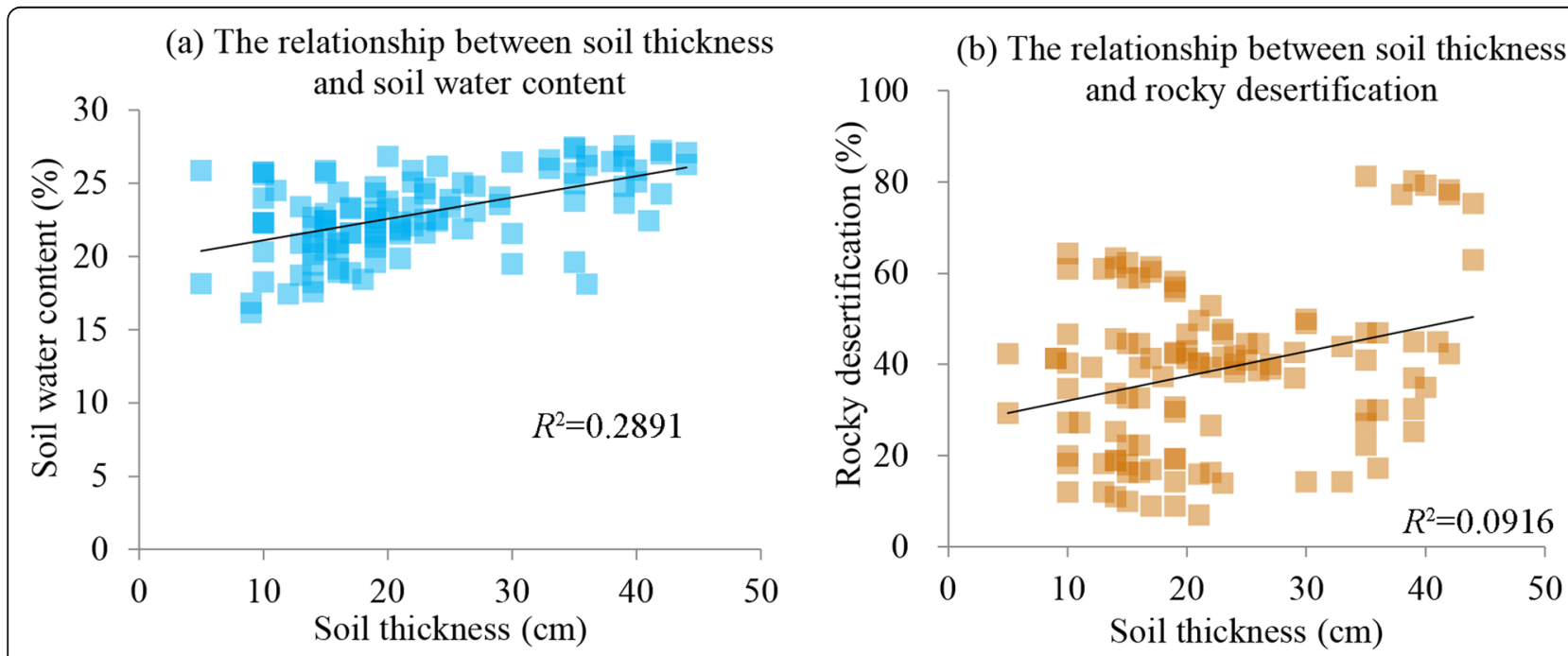

Fig. 5 Correlations between soil thickness and soil water content as well as proportion of rocky desertification in artificial forests 
Table 3 Driving factors associated with rocky desertification in natural karst recovery areas

\begin{tabular}{llll}
\hline Category & Independent variable & Correlation coefficients & Contribution (\%) \\
\hline Climatic variables & Precipitation & $0.592^{\mathrm{a}}$ & 23.73 \\
& Temperature & 0.001 & 4.79 \\
Topography and soil & Altitude & $0.204^{\mathrm{a}}$ & 7.43 \\
& Slope & $0.008^{\mathrm{b}}$ & 5.53 \\
& Soil thickness & 0.045 & 23.42 \\
Socioeconomic variables & Soil moisture content & $0.104^{\mathrm{b}}$ & 11.28 \\
& Population & 0.201 & 5.05 \\
& GDP & 0.001 & 4.21 \\
& Traffic density & 0.001 & 10.14 \\
& Construction area & $0.109^{\mathrm{b}}$ & 4.42
\end{tabular}

Standardized coefficients are reported as above. Parameters with relative contribution were identified by multiple regressions. ${ }^{\mathrm{a}} P<0.01 ;{ }^{\mathrm{b}} P<0.05$

drought pressure on karst areas is high, and creates a necessity for controlling forest vulnerability to limited water resources; this can be done with specific management objectives. Being an extremely important component of ecosystem services, forest ecosystems that increase drought stress will directly affect ecosystem services (Liedl et al. 2003). Managers must decide whether to reduce or mitigate drought stress, impacting decisions on whether the supply or demand for water is necessary from the perspective of forest management (Loaiciga et al. 2000). Results from this study demonstrate that forest managers in karst areas should pay more attention to the calculation of water balance while reducing negative impacts by man-made factors.

In karst areas, rock dissolution and soil loss are confounded, leading to a radical change in disturbances associated with soil thickness (Mahle et al., 2000). While plantations can provide a wide range of ecological services from wood production to soil erosion control, planted forests also restrict runoff while consuming excess water (Makinen et al. 2002). Such excessive consumption of water resources will eventually upset the ecological balance on which human beings and natural ecosystems depend for their survival, and which, paradoxically, is contrary to the concept of ecological restoration (Fan et al. 2018; Yang et al. 2019). Results from this study showed that from 2000 to 2010, there was an increase in the sensitivity to rocky desertification in southeastern Chongqing. By comparing forest plantations to natural forests, we found that planted forests were positively correlated to rocky desertification sensitivity. The reason for this is human interference on karst forest ecosystems (Panno et al. 2001). When interference with the structure or function of these forest ecosystems exceeds a certain threshold, an effect ensues.

\section{The importance of soil thickness}

We found in this study that changes in temperature and precipitation are key driving factors of mostly soil thickness and increase in exposed-rock areas, but what is noteworthy in this study, soil thickness is a key limiting factor in karst areas. Many studies have reported that soil thickness in karst areas significantly

Table 4 Driving factors associated with rocky desertification in artificial karst forest areas

\begin{tabular}{llll}
\hline Category & Independent variable & Correlation coefficients & Contribution (\%) \\
\hline Climatic variables & Precipitation & $0.42^{\mathrm{a}}$ & 22.13 \\
Topography and soil & Temperature & 0.011 & 4.22 \\
& Altitude & $0.104^{\mathrm{a}}$ & 3.72 \\
& Slope & $0.012^{\mathrm{b}}$ & 2.51 \\
Socioeconomic variables & Soil thickness & 0.472 & 24.42 \\
& Soil moisture content & $0.102^{\mathrm{b}}$ & 12.15 \\
& Population & 0.207 & 5.23 \\
& GDP & 0.001 & 8.21 \\
& Traffic density & 0.107 & 10.3 \\
\end{tabular}


affect ecological processes, vegetation, and drought occurrence (Xu et al. 2013).

Some studies found that soil thickness is regulated by the supply of inorganic nutrients and water resources to the plant community and by the type of karst area. Such studies also found that soil thickness has the highest correlations, mainly because carbonates are the basis of karst soils. When the air-water-rock-biota continuum interacts, it forms unique ecosystems that comprise of material, energy, structure, and function. Characteristically, karst forests are ecologically sensitive, having a low capacity for environmental. Karst forests have a weak ability to withstand disturbance, and have a weak capacity for self-recovery (Scanlon et al. 2003).

Our study also found that rainfall accounted for $23.73 \%$, while soil thickness accounted for $23.42 \%$ of the relative contribution on rocky desertification in natural karst recovery areas. Potential reasons for this could be that karst areas are mainly distributed in southwestern China where zonal rainfall exceeds $1000 \mathrm{~mm}$ per annum, indicating that rainfall is a key controlling factor in rocky desertification. This means that the regional climate meets the water requirements for plant production within the unique geological structure of karst forests, resulting in an increase in soil thickness (Kong et al., 2015b). This also validates our hypothesis that soil thickness is a key limiting factor in karst areas. Furthermore, the amount of water and ecological services that a forest provides and the strategies to alleviate water shortages must also be taken into account in the management of forest health and resilience (Smith et al. 2003).

We found that soil thickness had the greatest influence among all karst impact factors on rocky desertification sensitivity in forest plantations. In addition, regression results showed that rainfall accounted for $22.13 \%$ of the relative contribution in desertification sensitivity, while soil thickness accounted for $24.42 \%$. A potential reason for this is that soil thickness is associated with rocky desertification (Tooth and Fairchild, 2003). Growth of large-scale planted forests resulted in an increase in evapotranspiration in the study area, exacerbating water shortages and disrupting the already fragile forest ecosystem. Although afforestation has temporarily reduced poverty and increased income in the region, soil thickness is one of the main limiting factors of ecological restoration in karst areas. As human disturbances intensify, soil thickness will gradually decrease.

This study addressed vulnerability of an ecosystem resulting from external disturbances (Wu et al. 2017). The vegetation-soil system is an inseparable holistic entity, and the mechanisms associated with its interactions are important in controlling ecosystem processes and for forest management strategies in areas of rocky desertification. Due to its unique dual hydrological structure and complex features, such as depressions and funnels, soil thickness in karst forests is characterized by multiple sources and high variability (Vacher and Mylroie, 2002). At the same time, various niche types (e.g., stone facings, stone ditches, and stone crevices) formed from bare surface rocks have significantly affected small-scale habitat heterogeneity.

\section{Policy implications}

Rocky desertification has become a major ecological problem that restricts regional economic and social development in the southwestern karst region of China (Sun et al. 2017). Due to human disturbances and unsustainable use of resources, ecological disasters, such as vegetation degradation and rocky desertification in karst areas, have become increasingly common and severe (Miao et al. 2012). Results from this study indicated that rocky desertification sensitivity factors can help with diagnosing of ecosystem structure and function, and play a decisive role in the stability of karst ecosystems. Therefore, an increased understanding of rocky desertification sensitivity in karst areas is instrumental for formulating effective restoration measures in degraded ecosystems in karst areas.

Under the influence of many natural and human factors, such as climate, topography, vegetation, and human disturbances, soil thickness in karst areas plays a key role in vegetation cover. It regulates the composition of plant communities, vegetation distribution, and biomass patterns. We conclude that soil thickness is one of the critical factors that restrict the ecological restoration of rocky desertification areas. Also it is a key factor affecting individual and plant community dynamics, species coexistence, and even ecosystem structure and functioning (White 2002).

\section{Conclusions}

Over the past 10 years, plantation forest acreage in karst areas has been continuously increasing. Results from this study showed that human activities such as planting of forests have an impact on the sensitivity of rocky desertification in karst areas. Moreover, we determined that large-scale forest plantations are unsuitable for fragile karst environments. Artificial forests in karst areas result in the thinning of soil, exacerbating rocky desertification. Many researchers believe it derives from short-term economic behavior that ignores consequences of ecological impacts. Furthermore, an increase in rocky desertification sensitivity has a negative effect on the development of ecological restoration strategies, which indicates that the best way to protect the karst environment is to keep it in its natural state.

Limiting human interference can help to protect the fragile ecology of karst areas. Also, forest plantations should not be allowed to flourish in such a vulnerable 
ecological environment with low water resources as karst areas. Changes in soil thickness significantly affected the environment, which is a strong indicator of the level of karst ecological security. This study offers some new insights into issues related to afforestation in karst areas. It also presents a strong argument for utilizing soil thickness to enhance vegetation restoration initiatives while avoiding potential ecological risks.

\section{Acknowledgements}

We would like to thank Kathryn Piatek for his help in writing this paper as well as journal editors and anonymous reviewers for their comments on an earlier version of this manuscript.

\section{Authors' contributions}

QX collected and analysed the data and was a major contributor in writing the manuscript. YX, JT, YL and QX made substantial contributions to the conception and design, the interpretation of data and writing of the manuscript. All authors read and approved the final manuscript.

\section{Funding}

This study was supported by the National Key R\&D Program of China (2016YFC0502304).

\section{Availability of data and materials}

The datasets analysed during the current study are available from the corresponding author upon request.

\section{Ethics approval and consent to participate}

Not applicable.

\section{Consent for publication}

Not applicable.

\section{Competing interests}

The authors declare that they have no competing interests.

\section{Author details}

${ }^{1}$ Key Laboratory of Eco-environments in Three Gorges Reservoir Region (Ministry of Education), Chongqing Key Laboratory of Plant Ecology and Resources Research in Three Gorges Reservoir Region, School of Life Sciences, Southwest University, Chongqing 400715, China. ${ }^{2}$ Chongqing University of Arts and Sciences, Chongqing 402160, China. ${ }^{3}$ College of Biology and Environmental Sciences, Jishou University, Jishou 416000, China.

Received: 17 May 2019 Accepted: 5 January 2020

Published online: 06 February 2020

\section{References}

Asante J, Dotson S, Hart E, Kreamer DK (2018) Water circulation in karst systems: comparing physicochemical and environmental isotopic data interpretation. Environ Earth Sci 77(11). https://doi.org/10.1007/s12665-018-7596-y

Bakalowicz M (2005) Karst groundwater: a challenge for new resources. Hydrogeol J 13(1):148-160. https://doi.org/10.1007/s10040-004-0402-9

Barral MP, Benayas JM, Meli P, Maceira NO (2015) Quantifying the impacts of ecological restoration on biodiversity and ecosystem services in agroecosystems: a global meta-analysis. Agric Ecosyst Environ 202:223-231. https://doi.org/10.1016/..agee.2015.01.009

Braitenberg C, Pivetta T, Rossi G, Ventura P, Betic A (2018) Karst caves and hydrology between geodesy and archeology: field trip notes. Geod Geodyn 9(3):262-269. https://doi.org/10.1016/j.geog.2017.06.004

Cao S (2016) A win-win path for institutional change. Time Soc 25(3):493-512. https://doi.org/10.1177/0961463×15577275

Cao SX (2012) Why China's approach to institutional change has begun to succeed. Econ Model 29(3):679-683. https://doi.org/10.1016/j.econmod.2012.01.012

Cao SX, Chen L, Xu CG, Liu Z (2007) Impact of three soil types on afforestation in China's loess plateau: growth and survival of six tree species and their effects on soil properties. Landscape Urban Plan 83:208-217
Chen H, Li DJ, Xiao KC, Wang KL (2018) Soil microbial processes and resource limitation in karst and non-karst forests. Funct Ecol 32(5):1400-1409. https:// doi.org/10.1111/1365-2435.13069

Cheng B, Lv Y, Zhan Y, Su D, Cao SX (2015) Constructing China's roads as works of art: a case study of "esthetic greenway" construction in the Shennongjia region of China. Land Degrad Dev 26(4):324-330. https://doi.org/10.1002/ldr.2210

Epting J, Page RM, Auckenthaler A, Huggenberger P (2018) Process-based monitoring andmodeling of karst springs - linking intrinsic to specific vulnerability. Sci Total Environ 625:403-415. https://doi.org/10.1016/j. scitotenv.2017.12.272

Fan DY, Zhang SR, Yan H, Wu Q, Xu XW, Wang XP (2018) Do karst woody plants control xylem tension to avoid substantial xylem cavitation in the wet season? Forest Ecosyst 5:40. https://doi.org/10.1186/s40663-018-0158-7

Feng Q, Ma H, Jiang XM, Wang X, Cao SX (2015) What has caused desertification in China? Sci Rep 5:15998. https://doi.org/10.1038/srep15998

Fleury P, Bakalowicz M, de Marsily G (2007) Submarine springs and coastal karst aquifers: a review. J Hydrol 339(1-2):79-92. https://doi.org/10.1016/j.jhydrol. 2007.03.009

Giesecke T, Bennett KD (2004) The Holocene spread of Picea abies (L.) karst. in Fennoscandia and adjacent areas. J Biogeogr 31(9):1523-1548. https://doi. org/10.1111/j.1365-2699.2004.01095.x

Gong C, Xu CG, Chen L, Cao SX (2012) Cost-effective compensation payments: a model based on buying green cover to sustain ecological restoration. Forest Policy Econ 14(1):143-147. https://doi.org/10.1016/j.forpol.2011.08.007

Gutierrez F, Parise M, DeWaele J, Jourde H (2014) A review on natural and human-induced geohazards and impacts in karst. Earth-Sci Rev 138:61-88. https://doi.org/10.1016/.earscirev.2014.08.002

Han GL, Liu CQ (2004) Water geochemistry controlled by carbonate dissolution: a study ofthe river waters draining karst-dominated terrain, Guizhou Province, China. Chem Geol 204:1-21. https://doi.org/10.1016/j.chemgeo.2003.09.009

He QF, Qiu SL, Jiang YJ, Wu Z, Liu ZQ (2016) Land-use change caused microbial pollution in a karst underground river, Chongqing, China. Environ Earth Sci 75:8. https://doi.org/10.1007/s12665-016-5530-8

Hywonen R, Olsson BA, Lundkvist H, Staaf H (2000) Decomposition and nutrient release from Picea abies (L.) karst. And Pinus sylvestris L.-logging residues. Forest Ecol Manag 126(2):97-112. https://doi.org/10.1016/s0378-1127(99)00092-4

Jiang CC, Shang D, Cao SX (2016) Managing institutional evolution to increase the likelihood of success: examples of guidance from Chinese history. Soc Indic Res 127(3):1157-1167. https://doi.org/10.1007/s11205-015-1010-x

Jiang ZC, Lian YQ, Qin XQ (2015) Rocky desertification in Southwest China: impacts, causes, and restoration. Earth-Sci Rev 132:1-12. https://doi.org/10. 1016/j.earscirev.2014.01.005

Kong DX, Miao CY, Borthwick AGL, Duan QY, Liu H, Sun QH, Ye AZ, Di ZH, Gong W (2015a) Evolution of the Yellow River Delta and its relationship with runoff and sediment load from 1983 to 2011. J Hydrol 520:157-167. https://doi.org/ 10.1016/j.jhydrol.2014.09.038

Kong DX, Miao CY, Wu JW, Duan QY, Sun QH, Ye AZ, Di ZH, Gong W (2015b) The hydro-environmental response on the lower Yellow River to the watersediment regulation scheme. Ecol Eng 79:69-79. https://doi.org/10.1016/j. ecoleng.2015.03.009

Larocque M, Mangin A, Razack M, Banton O (1998) Contribution of correlation and spectral analyses to the regional study of a large karst aquifer (Charente, France). J Hydrol 205:217-231. https://doi.org/10.1016/s0022-1694(97)00155-8

Li C, Zheng H, Li SZ, Chen XS, Li J, Zeng WH, Liang YC, Polasky S, Feldman MW, Ruckelshaus M, Ouyang ZY, Daily C (2015) Impacts of conservation and human development policy across stakeholders and scales. PNAS 112(24): 7396-7401. https://doi.org/10.1073/pnas.1406486112

Li S, Ren HD, Xue L, Chang J, Yao XH (2014) Influence of bare rocks on surrounding soil moisture in the karst rocky desertification regions under drought conditions. CATENA 116:157-162. https://doi.org/10.1016/j.catena.2013.12.013

Liedl R, Sauter M, Huckinghaus D, Clemens T, Teutsch G (2003) Simulation of the development of karst aquifers using a coupled continuum pipe flow model. Water Res Res 39(3). https://doi.org/10.1029/2001wr001206

Loaiciga HA, Maidment DR, Valdes JB (2000) Climate-change impacts in a regional karst aquifer, Texas, USA. J Hydrol 227:173-194. https://doi.org/10. 1016/s0022-1694(99)00179-1

Mahle BJ, Personne JC, Lods GF, Drogue C (2000) Transport of free and particulate-associated bacteria in karst. J Hydrol 238:179-193. https://doi.org/ 10.1016/s0022-1694(00)00324-3

Makinen H, Nojd P, Kahle HP, Neumann U, Tveite B, Mielikainen K, Rohle H, Spiecker H (2002) Radial growth variation of Norway spruce (Picea abies karst.) across 
latitudinal and altitudinal gradients in central and northern Europe. For Ecol Manag 171(3):243-259. https://doi.org/10.1016/s0378-1 127(01)00786-1

Miao CY, Yang L, Chen XH, Gao Y (2012) The vegetation cover dynamics (19822006) in different erosion regions of the Yellow River Basin, China. Land Degrad Dev 23(1):62-71. https://doi.org/10.1002/ldr.1050

Panno SV, Hackley KC, Hwang HH, Kelly WR (2001) Determination of the sources of nitrate contamination in karst springs using isotopic and chemical indicators. Chem Geol 179:113-128. https://doi.org/10.1016/s0009-2541(01)00318-7

Scanlon BR, Mace RE, Barrett ME, Smith B (2003) Can we simulate regional groundwater flow in a karst system using equivalent porous media models? Case study, Barton Springs Edwards aquifer, USA. J Hydrol 276:137-158. https://doi.org/10.1016/s0022-1694(03)00064-7

Smith H, Wood PJ, Gunn J (2003) The influence of habitat structure and flow permanence on invertebrate communities in karst spring systems. Hydrobiologia 510:53-66. https://doi.org/10.1023/b:hydr.0000008501.55798.20

Stephens C (2017) Planet human versus planet earth-time for some win-win evidence. Environ Res Lett 12(10):101002. https://doi.org/10.1088/1748-9326/aa822c

Sun QH, Miao CY, Duan QY (2017) Changes in the spatial heterogeneity and annual distribution of observed precipitation across China. J Clim 30(23): 9399-9416. https://doi.org/10.1175/jcli-d-17-0045.1

Tang J, Tang XX, Qin YM, He QS, Yi Y, Ji ZL (2019) Karst rocky desertification progress: soil calcium as a possible driving force. Sci Total Environ 649:12501259. https://doi.org/10.1016/j.scitotenv.2018.08.242

Tooth AF, Fairchild IJ (2003) Soil and karst aquifer hydrological controls on the geochemical evolution of speleothem-forming drip waters, crag cave, Southwest Ireland. J Hydrol 273:51-68. https://doi.org/10.1016/s00221694(02)00349-9

Vacher HL, Mylroie JE (2002) Eogenetic karst from the perspective of an equivalent porous medium. Carbonate Evaporite 17(2):182-196. https://doi. org/10.1007/bf03176484

Wang WL, Körner C, Zhang ZM, Wu RD, Geng YP, Shi W, Ou XK (2013) No slope exposure effect on alpine treeline position in the three parallel Rivers region SW China. Alpine Bot 123(2):87-95. https:/doi.org/10.1007/s00035-013-0118-3

White WB (2002) Karst hydrology: recent developments and open questions. Eng Geol 65:85-105. https://doi.org/10.1016/s0013-7952(01)00116-8

Wu JW, Miao CY, Zhang XM, Yang TT, Duan QY (2017) Detecting the quantitative hydrological response to changes in climate and human activities. Sci Total Environ 586:328-337. https://doi.org/10.1016/j.scitotenv.2017.02.010

Xiao Q. Hu D (2017) Dynamic characteristics of a water resource structure in an urban ecological system: structure modelling based on input-occupancyoutput technology. J Clean Prod 153:548-557. https://doi.org/10.1016/j. jclepro.2016.02.101

Xiao RB, Ouy ZHY, Wang XK, Zhao TQ (2005) Sensitivity of rocky desertification and its spatial distribution in southwestern China. Chin J Ecol 24:551-554

Xu XB, Tan Y, Yang GS (2013) Environmental impact assessments of the three gorges project in China: issues and interventions. Earth-Sci Rev 124:115-125. https://doi.org/10.1016/j.earscirev.2013.05.007

Yang Y, Wang L, Wendroth O, Liu BY, Cheng CC, Huang TT, Shi YZ (2019) Is the laser diffraction method reliable for soil particle size distribution analysis? Soil Sci Soc Am J. https://doi.org/10.2136/sssai2018.07.0252

You HY (2017) Orienting rocky desertification towards sustainable land use: an advanced remote sensing tool to guide the conservation policy. Land Use Policy 61:171-184. https://doi.org/10.1016/j.landusepol.2016.11.024

Zhang JY, Dai MH, Wang LC, Su WC (2016a) Household livelihood change under the rocky desertification control project in karst areas, Southwest China. Land Use Policy 56:8-15. https://doi.org/10.1016/j.landusepol.2016.04.009

Zhang JZ, Zhao TY, Jiang CC, Cao SX (2016b) Opportunity cost of water allocation to afforestation rather than conservation of natural vegetation in China. Land Use Policy 50:67-73. https://doi.org/10.1016/j.landusepol.2015.09.008

Zhang ZM, van Coillie F, Ou XK, de Wulf R (2014) Integration of satellite imagery, topography and human disturbance factors based on canonical correspondence analysis ordination for mountain vegetation mapping: a case study in Yunnan, China. Remote Sens 6(2):1026-1056. https://doi.org/10.3390/rs6021026

\section{Submit your manuscript to a SpringerOpen ${ }^{\circ}$ journal and benefit from:}

- Convenient online submission

- Rigorous peer review

- Open access: articles freely available online

- High visibility within the field

- Retaining the copyright to your article

Submit your next manuscript at $\boldsymbol{\sim}$ springeropen.com 